\title{
Pembelajaran berbasis proyek dalam meningkatkan keterampilan pemecahan masalah siswa
}

\author{
Rahmiati Darwis ${ }^{\mathrm{a}, 1, *}$, Muhammad Rizal Hardiansyah $\mathrm{M}^{\mathrm{a}, 2}$ \\ ${ }^{a}$ IAIN Ambon. Jl. Dr. H. Tarmizi Taher, Kebun Cengkeh, Batu Merah Atas, Kota Ambon 97128, Indonesia \\ ${ }^{1}$ rahmiati.darwis@iainambon.ac.id *, ${ }^{2}$ rizalscience@iainambon.ac.id \\ * Korespondensi Penulis
}

\section{ARTICLE INFO}

Article history

Received June 26, 2020

Revised June 26, 2020

Accepted June 27, 2020

Available Online June 30, 2020

Keywords

Project based learning

Integrated learning

Connected type

Problem solving skill

\section{ABSTRACT}

The purpose of this study was to analyze the enhancement of the middle school student problem solving skill through implementation of Project Based Learning (PjBL) model in integrated science learning Connected type. This research used quasi-experiment method with the static group pretest-posttest design. The subject of the research was the students of first grade in Ambon with total number of participants were 42 by using simple random sampling. Data was collected through problem solving skill test and questionnaire response of students about implementation of PjBL model. The technique of analyzing data used normality and homogenous test, $N$-gain test and t-test were tested by IBM SPSS Statistics 22. The result of this study showed that enhancement student's problem solving skill showed by $N$-gain problem solving skill in experiment class is 0,73 (high) and N-gain problem solving skill in control class is 0,63 (moderate). Results of t-test value of problem solving skill got Sig.(t-tailed) $0.000<\alpha$, show that PjBL model can help the students to enhance problem solving skill better than the used of traditional model. Students give positive response to the PjBL model in integrated science learning type Connected.

Penelitian ini bertujuan untuk menganalisis peningkatan keterampilan pemecahan masalah siswa SMP/MTs melalui penerapan model pembelajaran Project Based Learning (PjBL) dalam pembelajaran IPA Terpadu tipe Connected. Penelitian ini menggunakan metode eksperimen semu dengan desain the static group pretest- posttest. Sejumlah siswa kelas VII $(\mathrm{N}=42)$ di Kota Ambon terlibat sebagai subjek penelitian yang diambil dengan teknik simple random sampling. Pengumpulan data dilakukan melalui tes keterampilan pemecahan masalah dan angket tanggapan siswa. Teknik pengolahan data melalui uji normalitas dan homogenitas, perhitungan $\mathrm{N}$-gain, dan uji-t dengan bantuan program IBM SPSS Statistics 22. Hasil analisis data menunjukkan bahwa peningkatan keterampilan pemecahan masalah ditunjukkan oleh $\mathrm{N}$-gain kelas eksperimen 0,73 (tinggi) sedangkan $\mathrm{N}$ gain kelas kontrol 0,63 (sedang). hasil uji t pada data nilai $\mathrm{N}$-gain keterampilan pemecahan masalah, diperoleh nilai signifikansi Sig. ( $t$ tailed) 0.000 yang menunjukkan hasil yang lebih kecil dari 0,050 yang berarti $\mathrm{H}_{0}$ ditolak dan $\mathrm{H}_{1}$ diterima. Oleh karena itu, pada taraf kepercayaan $95 \%(\alpha=5 \%)$ diperoleh kesimpulan bahwa model pembelajaran $\mathrm{PjBL}$ lebih baik dalam meningkatkan keterampilan pemecahan masalah siswa dibandingkan dengan pembelajaran yang tidak menggunakan model PjBL.

This is an open access article under the CC-BY-SA license.

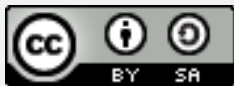




\section{Pendahuluan}

Saat ini dunia telah memasuki era revolusi industri 4.0. Era ini ditandai oleh kemajuan dan perubahan yang sangat cepat dalam teknologi baru. Perubahan yang terjadi pada era ini tidak dapat dihindari oleh siapapun sehingga dibutuhkan bekal yang matang agar siap menghadapi tantangan jaman dan mampu bersaing dalam skala global. Salah satu bekal yang perlu dilakukan adalah peningkatan kualitas sumber daya manusia (SDM) melalui jalur pendidikan, mulai dari pendidikan dasar, menengah hingga ke tingkat perguruan tinggi. Hal ini merupakan salah satu kunci untuk mampu mengikuti perkembangan revolusi industri 4.0.

Dalam dunia pendidikan, siswa perlu dibekali pengetahuan, sikap, dan keterampilan yang memadai untuk menghadapi tantangan pendidikan diera revolusi industri 4.0. Keterampilan dasar seperti menulis, membaca, dan berhitung tidak cukup dalam menghadapinya. World Economic Forum telah merilis laporan dengan melakukan survey kepada para pejabat kepala SDM di beberapa perusahaan terkemuka dunia yang mengungkap beberapa keterampilan yang wajib dimiliki untuk menghadapi revolusi industri 4.0, salah satunya adalah keterampilan pemecahan masalah.

Keterampilan pemecahan masalah merupakan salah satu bentuk keterampilan berpikir yang harus dimiliki oleh siswa untuk mampu bertahan dalam menghadapi tantangan masa depan. Keterampilan pemecahan masalah sangat penting pengaplikasiannya dalam kehidupan sehari-hari. Kaya, dkk (2014, p.300) menyatakan bahwa keterampilan pemecahan masalah adalah keterampilan dasar yang harus dimiliki oleh setiap orang dan dapat digunakan diberbagai bidang dalam kehidupan seharihari. Keterampilan pemecahan masalah penting dikembangkan melalui pembelajaran Ilmu Pengetahuan Alam (IPA). Ketidakmampuan pembelajaran IPA dalam mengembangkan keterampilan berpikir dapat terlihat dari beberapa permasalahan yang terjadi dalam kehidupan sehari-hari seperti kurangnya kepedulian terhadap masalah lingkungan. Hal ini menunjukkan bahwa pendidikan IPA yang diperoleh siswa di sekolah tidak mendalam karena dapat diterapkan dalam kehidupannya.

Berdasarkan hasil observasi pembelajaran IPA pada salah satu MTs di Kota Ambon, diperoleh fakta bahwa pembelajaran IPA yang berlangsung di kelas masih berpusat pada guru (teacher centered) dimana guru mengambil peranan yang paling besar sedangkan siswa cenderung pasif dalam pembelajaran. Siswa pasif dalam pembelajaran karena metode pembelajaran yang diajarkan guru didominasi dengan metode ceramah. Kegiatan siswa selama pembelajaran terbatas pada kegiatan mencatat, menyimak, dan menghafal. Guru kurang melatih siswa dalam mengembangkan kemampuan berpikir, sehingga siswa kurang optimal dalam memahami materi, akibatnya hasil belajar rendah yang dilihat dari Kriteria Ketuntasan Minimal (KKM) siswa pada mata pelajaran IPA semester sebelumnya kurang dari $65 \%$.

Biggs dalam Toharudin, dkk (2011, p.51), jika guru ingin membuat siswanya memahami apa yang dipelajari, guru harus mampu mendorong dan membantu siswanya untuk mengonstruksikan sendiri makna-makna dari apa yang telah dipelajarinya. Keberhasilan proses pembelajaran terjadi apabila peserta didik betul-betul memahami apa yang dipelajarinya (deep learning) sehingga ia mampu mengaplikasikannya dalam kehidupan sehari-hari.

Salah satu tujuan pembelajaran IPA dalam kurikulum 2013 adalah agar siswa memiliki kompetensi untuk mengembangkan kemampuan berpikir analisis induktif dan deduktif dengan menggunakan konsep dan prinsip IPA dalam menjelaskan berbagai peristiwa alam dan menyelesaikan masalah baik secara kualitatif maupun kuantitatif (Permendikbud, 2013, p.87). Tujuan tersebut sangat sesuai untuk meningkatkan keterampilan pemecahan masalah siswa. Oleh karena ini, pemecahan masalah merupakan keterampilan yang harus dikuasai. Untuk menguasainya, kita perlu melatihnya melalui strategi pembelajaran yang tepat.

Project Based Learning (PjBL) dapat mewadahi permasalahan rendahnya hasil belajar siswa tersebut. Pembelajaran ini tidak lagi menciptakan pengalaman belajar yang berpusat pada aktivitas guru (teacher centered) tetapi sudah menerapkan pembelajaran yang bersifat student centered. PjBL merupakan suatu model pembelajaran yang dapat mengembangkan keterampilan berpikir siswa melalui suatu proyek yang diselesaikan secara berkelompok. PjBL memiliki potensi yang besar dalam membuat pengalaman belajar yang lebih menarik dan bermakna bagi siswa. Dalam pembelajaran ini, siswa mengambil peranan yang lebih besar daripada guru, siswa menjadi lebih 
aktif dalam belajar sedangkan guru sebagai fasilitator dan mengevaluasi proyek atau produk hasil kinerja siswa, dalam hal ini pembelajaran lebih berpusat pada siswa (student centered).

PjBL merupakan pembelajaran yang didahului dengan pertanyaaan mendasar dengan proyek sebagai tugas pembelajaran. Melalui pembelajaran ini, siswa dapat mencari tahu sendiri, menggali, mengolah, mendesain, serta menyelesaikan masalah sendiri dengan menerapkan konsep yang dipelajari sehingga menghasilkan produk atau proyek yang dapat digunakan dalam mengatasi suatu permasalahan (The George Lucas Educational, 2005). Berdasarkan hasil penelitian Baran \& Maskan (2010, p.244) menyatakan bahwa siswa dapat meningkatkan kinerja, pemahaman konsep, dan kepercayaan diri melalui PjBL. Hasil penelitian lain dikemukakan oleh Ismuwardani, dkk (2019, p.51) menyatakan bahwa implementasi PjBL meningkatkan kreativitas dan kepercayaan diri siswa secara signifikan. Jamaludin (2013, p.56) juga menyatakan bahwa penerapan PjBL memberikan pengaruh terhadap keterampilan berpikir kritis, kreatif, dan sikap ilmiah siswa. Rezeki, dkk (2015, p.74) mengungkapkan metode PjBL disertai dengan peta konsep siswa SMA dapat meningkatkan prestasi belajar siswa pada aspek kognitif. Berdasarkan beberapa hasil penelitian tersebut disimpulkan bahwa penerapan PjBL dapat memberikan banyak manfaat yang positif terhadap peningkatan kemampuan maupun keterampilan siswa dari tingkat dasar hingga keterampilan berpikir tingkat tinggi.

Pembelajaran IPA di sekolah SMP/MTs dengan menerapkan PjBL dalam pembelajaran terpadu diharapkan dapat meningkatkan kemampuan siswa dalam mengembangkan keterampilan pemecahan masalah, sehingga pembelajaran IPA yang diperoleh siswa lebih bermakna dan diterapkan dalam kehidupan sehari-hari. Siswa tidak lagi hanya duduk diam menyimak penjelasan guru, melainkan siswa juga ikut berpikir dengan mencari tahu, menggali, mengolah, serta menemukan sendiri konsep pengetahuannya. Keterampilan memecahkan masalah yang baik pada siswa dapat memberikan dasar kepada mereka untuk menemukan pola belajar bermaksa dalam proses pembelajaran, sehingga konsep materi pelajaran dapat lebih membekas. Hal ini akan mempengaruhi ketuntasan belajar IPA yang rendah pada siswa semester sebelumnya dapat lebih ditingkatkan.

Materi IPA yang ditinjau dalam penelitian ini adalah energi dan perubahannya, materi dan sifatnya. Materi ini dipilih karena pada materi ini terdiri dari beberapa subtopik yang saling berhubungan, sehingga dengan diajarkan secara terpadu, siswa diharapkan mampu menganalisis keterkaitan antara subtopik tersebut. Pada penelitian ini, materi tersebut diajarkan dengan terpadu tipe connected yaitu tipe pembelajaran terpadu dengan memandang IPA sebagai satu disiplin ilmu yang menghubungkan subtopik energi dan perubahannya serta materi dan sifatnya dengan harapan siswa mampu menyerap konsep atau materi secara utuh dan dapat menemukan solusi dari berbagai permasalahan sains yang ada. Selain itu, melalui pembelajaran terpadu tipe connected dapat membantu siswa dalam menguasai materi IPA secara bermakna dan menyeluruh (Trianto, 2014, p.39). Pembelajaran tipe terpadu connected dipilih karena berdasarkan tipe pembelajaran terpadu Fogarty (1991a, p.25), pembelajaran tipe terpadu connected merupakan tipe pembelajaran terpadu yang sesuai diterapkan dalam pembelajaran IPA, jika IPA dipandang sebagai satu disiplin ilmu. Selain itu, berdasarkan hasil penelitian sebelumnya, Nofrianita $(2015$, p.76) yang menyatakan bahwa penerapan pembelajara IPA terpadu tipe connected dapat meningkatkan penguasaan konsep dan keterampilan berpikir kritis siswa.

Bertolak dari masalah pendidikan dalam pembelajaran IPA yang terjadi dan potensi solusi alternatif yang telah diuraikan, maka peneliti tertarik untuk melakukan penelitian pada pembelajaran IPA. Oleh karena itu sebagai judul pada penelitian ini yaitu project Based Learning (PjBL) dalam pembelajaran IPA terpadu tipe connected untuk meningkatkan keterampilan pemecahan masalah siswa pada subtopik energi dan perubahannya, materi dan sifatnya.

\section{Metode}

\subsection{Jenis Penelitian}

Penelitian ini dilaksanakan dengan tujuan untuk mengetahui perbedaan peningkatan keterampilan pemecahan masalah siswa setelah diajar melalui model pembelajaran PjBL dalam pembelajaran terpadu tipe connected dan model pembelajaran konvesional. Untuk pelaksanaan penelitian tersebut maka metode yang digunakan adalah metode eksperimen (experimental 
research). Jenis metode eksperimen yang digunakan dalam penelitian ini adalah eksperimen semu (quasi experimental). Jenis metode eksperimen semu dapat memberikan informasi yang merupakan perkiraan terhadap informasi yang dapat diperoleh melalui eksperimen yang sebenarnya dalam keadaan yang tidak memungkinkan untuk mengontrol semua variabel yang relevan (Fraenkel \& Wallen, 2007, p.268).

\subsection{Waktu dan Tempat Penelitian}

Penelitian ini dilakukan pada semester ganjil tahun ajaran 2019/2020. Populasi dalam penelitian ini adalah seluruh siswa kelas VII pada salah satu MTs di kota Ambon Provinsi Maluku yang terdaftar pada semester ganjil Tahun Ajaran 2019/2020 sebanyak 97 siswa (4 kelas). Penentuan sampel dilakukan dengan teknik simple random sampling. Teknik simple random sampling merupakan teknik pengambilan anggota sampel dari populasi dilakukan secara acak. Pengambilan dengan teknik ini dilakukan karena populasi bersifat homogen artinya setiap kelas memiliki tingkat kemampuan yang sama. Populasi tersebut bersifat homogen karena pada saat penentuan kelas, siswa dibagi ke dalam kelas secara acak tanpa pertimbangan dari kemampuan kognitifnya. Sekolah tersebut tidak diberlakukan adanya kelas yang unggul (kelas dengan siswa yang berkemampuan tinggi) dan kelas yang kurang unggul (kelas dengan siswa yang berkemampuan rendah). Sampel yang diperoleh secara acak dan diambil dua kelas yang digunakan dalam penelitian ini. Kedua kelas tersebut dibedakan menjadi dua kelompok, yaitu satu kelas eksperimen dan satu kelas kontrol.

\subsection{Prosedur Penelitian}

Desain yang digunakan penelitian ini adalah The static group pretest-posttest artinya pengambilan kelompok secara acak dan memberlakukan pretest untuk semua kelompok. Skor pretest dibandingkan dengan skor posttest untuk dihitung kenaikan atau perubahan skor yang diperoleh (Fraenkel \& Wallen, 2007, p.269). Penelitian ini menggunakan dua kelas yaitu kelas eksperimen (siswa yang belajar melalui model PjBL dalam pembelajaran terpadu tipe connected) dan kelas kontrol (siswa yang belajar melalui model pembelajaran konvensional). Kedua kelas diberi perlakuan yang berbeda dan keduanya diberi tes awal dan tes akhir.

Tabel 1. Desain The Static Group Pretest-Posttest

\begin{tabular}{ccc}
\hline Pretest & Perlakuan & Posttest \\
\hline $\mathrm{O}_{1}$ & $\mathrm{X}_{1}$ & $\mathrm{O}_{2}$ \\
$\mathrm{O}_{1}$ & $\mathrm{X}_{2}$ & $\mathrm{O}_{2}$ \\
\hline
\end{tabular}

Keterangan:

$\mathrm{X}_{1}=$ Perlakuan yang diberikan pada kelas eksperimen (PjBL dengan tipe connected $)$

$\mathrm{X}_{2}=$ Perlakuan yang diberikan pada kelas kontrol (Pembelajaran tradisional)

$\mathrm{O}_{1}=$ Pretest untuk mengukur keterampilan pemecahan masalah siswa

$\mathrm{O}_{2}=$ Posttest untuk mengukur keterampilan pemecahan masalah siswa

Penelitian ini dilakukan melalui tiga tahap yaitu tahap perencanaan, tahap pelaksanaan, dan tahap akhir. Pada tahap perencanaan ada delapan kegiatan yang dilakukan sebelum memasuki tahap pelaksanaan. Kegiatan perencanaan yang dilakukan yaitu: (1) menentukan masalah yang akan dikaji melalui studi pendahuluan dengan mengamati kegiatan pembelajaran IPA di dalam kelas dan melakukan wawancara terhadap guru mata pelajaran IPA di sekolah, (2) melakukan studi literatur dengan tujuan untuk memperoleh teori yang akurat mengenai permasalahan yang akan dikaji, (3) melakukan studi kurikulum 2013 tingkat SMP/MTs mengenai materi ajar yang dijadikan penelitian untuk mengetahui kompetensi dasar yang ingin dicapai, (4) menyusun perangkat pembelajaran untuk tiap pertemuan untuk masing-masing kelas, (5) menyusun instrumen penelitian berupa instrumen keterampilan pemecahan masalah (6) meminta penimbangan instrumen penelitian kepada ahli, (7) melakukan uji coba instrumen penelitian, dan (8) menganalisis hasil uji coba instrumen penelitian dan menentukan soal yang layak digunakan sebagai instrumen penelitian.

Tahap pelaksanaan dilakukan pada salah satu sekolah MTs di kota Ambon. Kegiatan yang dilakukan pada saat pelaksanan penelitian terdiri dari (1) memberikan tes awal pada kedua kelas sampel, (2) memberikan perlakuan kepada kedua kelas, kelas eksperimen berupa model PjBL sedangkan kelas kontrol berupa model konvensional, (3) melakukan observasi keterlaksanaan 
model selama proses pembelajaran berlangsung, dan (4) memberikan tes akhir pada kedua kelas untuk mengetahui peningkatan keterampilan pemecahan masalah setelah diberi perlakuan.

Tahap akhir berupa kegiatan yang dilakukan setelah melaksanakan penelitian pada salah satu sekolah. Terdapat tujuh kegiatan yang dilakukan pada tahap akhir yaitu (1) melakukan penskoran terhadap hasil tes awal dan tes akhir untuk kedua kelas, (2) melakukan analisis data menggunakan SPSS, (3) melakukan analisis data angket tanggapan siswa, (4) mengambil kesimpulan penelitian, dan (5) membuat laporan hasil penelitian.

\subsection{Instrumen Penelitian}

Untuk memperoleh data dalam penelitian ini digunakan dua jenis instrumen, yaitu tes keterampilan pemecahan masalah dan angket tanggapan siswa terhadap model pembelajaran yang digunakan. Rincian instrumen penelitian dapat dilihat pada Tabel 2.

Tabel 2. Instrumen Penelitian

\begin{tabular}{|c|c|c|c|c|c|}
\hline No. & Jenis Data & $\begin{array}{c}\text { Sumber } \\
\text { Data }\end{array}$ & $\begin{array}{c}\text { Teknik } \\
\text { Pengumpulan }\end{array}$ & Instrumen & Jumlah Butir \\
\hline 1. & $\begin{array}{c}\text { Keterampilan } \\
\text { pemecahan masalah }\end{array}$ & Siswa & Tes Essay & $\begin{array}{c}\text { Tes Soal Essay } \\
\text { Keterampilan } \\
\text { pemecahan Masalah }\end{array}$ & 5 \\
\hline 2. & $\begin{array}{c}\text { Angket Tanggapan } \\
\text { terhadap Model } \\
\text { Pembelajaran }\end{array}$ & Siswa & Kuesioner & $\begin{array}{c}\text { Kuesioner Tanggapan } \\
\text { Siswa terhadap Model } \\
\text { PjBL }\end{array}$ & 7 \\
\hline
\end{tabular}

Instrumen untuk mengukur keterampilan pemecahan masalah siswa diukur melalui tes soal essay yang memuat indikator keterampilan pemecahan masalah siswa. Indikator pemecahan masalah yang digunakan pada penelitian ini adalah menganalisis permasalahan, mengumpulkan data/informasi, dan mengusulkan solusi permasalahan. Setiap soal tes keterampilan pemecahan masalah mengandung ketiga indikator pemecahan masalah tersebut. Fenomena yang disajikan pada soal tes keterampilan pemecahan masalah adalah fenomena yang berhubungan dengan konteks kehidupan sehar-hari dari konsep materi dan energi.

Uji coba instrumen keterampilan pemecahan masalah yang telah disusun peneliti dilakukan pada siswa kelas VIII pada salah satu sekolah tingkat menengah pertama di kota Ambon. Soal tes yang diujicobakan masing-masing sebanyak 5 butir soal essay. Analisis instrumen dilakukan untuk menentukan validitas, reliabilitas, tingkat kesukaran, dan daya pembeda menggunakan software Anates V4.

Hasil analisis reliabilitas instrumen soal keterampilan pemecahan masalah diperoleh koefisien reliabilitasnya adalah 0,76 dengan kriteria tinggi. Hasil analisis daya pembeda, tingkat kesukaran, dan validitas soal tes keterampilan pemecahan masalah disajikan pada Tabel 3 .

Tabel 3.

Rekapitulasi Hasil Uji Coba Soal Tes Keterampilan Pemecahan Masalah

\begin{tabular}{|c|c|c|c|c|c|c|c|}
\hline \multirow[t]{2}{*}{ No. } & \multicolumn{2}{|c|}{ Daya Beda } & \multicolumn{2}{|c|}{$\begin{array}{c}\text { Tingkat } \\
\text { Kesukaran } \\
\end{array}$} & \multicolumn{2}{|c|}{ Validitas } & \multirow[t]{2}{*}{ Keputusan } \\
\hline & Nilai & Kriteria & Nilai & Kriteria & Nilai & Kriteria & \\
\hline 1. & 0,275 & Cukup & 0,767 & Mudah & 0,722 & Tinggi & Dipakai \\
\hline 2. & 0,250 & Cukup & 0,770 & Mudah & 0,731 & Tinggi & Dipakai \\
\hline 3. & 0,285 & Cukup & 0,812 & Mudah & 0,842 & Sangat Tinggi & Dipakai \\
\hline 4. & 0,208 & Cukup & 0,770 & Mudah & 0,728 & Tinggi & Dipakai \\
\hline 5. & 0,500 & Baik & 0,770 & Mudah & 0,820 & Sangat Tinggi & Dipakai \\
\hline
\end{tabular}

Berdasarkan rekapitulasi hasil uji coba soal tes keterampilan pemecahan masalah yang berbentuk soal essay, diperoleh soal yang digunakan sebanyak 5 butir soal.

\subsection{Teknik Analisis Data}

\subsubsection{Pengolahan Data Tes (Tes Keterampilan Pemecahan Masalah)}

Data hasil penelitian dianalisis secara statistik dengan melakukan perhitungan $\mathrm{N}$-gain dengan bantuan Microsoft office Excel. Dimana rumus N-gain menurut Hake (1999, p.5):

$$
\mathrm{N} \text {-gain }=\frac{\text { skor postest }- \text { skor pretest }}{\text { skorideal }- \text { skor pretest }}
$$


Tabel 4.

Kategori Tingkat gain yang Dinormalisasi

\begin{tabular}{cc}
\hline Batasan & Kategori \\
\hline$<\mathrm{g}>>0,7$ & Tinggi \\
$0,3 \leq<\mathrm{g}>\leq 0,7$ & Sedang \\
$<\mathrm{g}><0,3$ & Rendah
\end{tabular}

Data $N$-gain yang diperoleh kemudian diuji prasyarat terlebih dahulu menggunakan uji normalitas dan homogenitas yang dilakukan dengan program IBM SPSS Statistics 22. Kemudian dilanjutkan melakukan pengujian hipotesis menggunakan uji-t satu pihak yang perhitungannya juga dilakukan dengan bantuan program IBM SPSS Statistics 22. Pada uji hipotesis ini, taraf signifikansi $(\alpha)$ yang digunakan adalah $5 \%$ atau 0,05 . Keputusan uji hipotesis ditentukan dengan kriteria: Jika Sig. $<0,05$ maka $\mathrm{H}_{0}$ ditolak dan $\mathrm{H}_{1}$ diterima.

\subsubsection{Pengolahan Angket Tanggapan Siswa}

Angket tanggapan digunakan untuk menganalisis tanggapan siswa terhadap pelaksanaan model pembelajaran PjBL dalam pembelajaran terpadu tipe connected pada materi subtopik energi dan perubahannya, serta materi dan sifatnya. Analisis yang dilakukan secara deskriptif dalam bentuk skala Likert, yaitu setiap pernyataan diikuti beberapa respon yang menunjukkan tingkatan. Respon atau tanggapan terhadap masing-masing pernyataan dinyatakan dalam empat kategori, yaitu Sangat Setuju (SS), Setuju (S), Tidak Setuju (TS), dan STS (Sangat Tidak Setuju). Bobot kategori untuk pernyataan positif yaitu $\mathrm{SS}=4, \mathrm{~S}=3, \mathrm{TS}=2$, dan $\mathrm{STS}=1$, sedangkan untuk pernyataan negatif, bobot kategori tiap tanggapannya adalah sebaliknya dari pernyataan positif yaitu $\mathrm{SS}=1, \mathrm{~S}=2, \mathrm{TS}=$ 3 , dan STS $=4$. Perhitungan secara keseluruhan dilakukan dengan mengalikan bobot kategori dengan jumlah siswa yang memilih kategori tersebut dan selanjutnya membaginya dengan jumlah siswa secara keseluruhan.

\section{Hasil dan Pembahasan}

\subsection{Hasil}

\subsubsection{Data Pencapaian Keterampilan Pemecahan Masalah (KPM)}

Data pencapaian keterampilan pemecahan masalah siswa diperoleh dengan menggunakan tes yang diujikan pada saat pretest dan postest berupa soal essay sebanyak 5 butir soal di mana tiap butir soal mencakup tiga indikator keterampilan pemecahan masalah yang digunakan pada penelitian ini. Indikator keterampilan pemecahan masalah yang diukur meliputi menganalisis masalah, mengumpulkan data/informasi yang menunjang pemecahan masalah, dan mengusulkan solusi pemecahan masalah. Rekapitulasi nilai pretes, postes, dan $\mathrm{N}$-gain dari keterampilan pemecahan masalah per indikator disajikan pada Tabel 5.

Tabel 5. Rekapitulasi Nilai Pretes, Postes, dan N-Gain Per Indikator Keterampilan Pemecahan Masalah

\begin{tabular}{cccccccc}
\hline Kelas & Tes & Xideal & Xmax & Xmin & $\bar{X}$ & G & <g> \\
\hline \multirow{3}{*}{ Eksperimen } & Pretest & 100 & 41 & 12 & 25,29 & \multirow{2}{*}{54,67} & 0,73 \\
& Posttest & 100 & 100 & 65 & 79,95 & & TINGGI \\
\hline \multirow{2}{*}{ Kontrol } & Kriteria Peningkatan & & & & 0 \\
& Posttest & 100 & 53 & 12 & 31,43 & 43,28 & 0,63
\end{tabular}

Kriteria Peningkatan

SEDANG

Berdasarkan Tabel 5 dapat dilihat bahwa adanya peningkatan keterampilan pemecahan masalah baik pada kelas eksperimen maupun pada kelas kontrol. Kelas eksperimen mengalami peningkatan dengan kategori tinggi sedangkan kelas kontrol mengalami peningkatan dengan kategori sedang. Kelas eksperimen mencapai peningkatan keterampilan pemecahan masalah tertinggi adalah pada indikator mengusulkan solusi pemecahan masalah, sedangkan peningkatan keterampilan pemecahan masalah yang relatif sama adalah pada indikator menganalisis permasalahan dan mengumpulkan data/informasi untuk memecahkan masalah. Untuk lebih jelasnya, histogram peningkatan keterampilan pemecahan untuk setiap indikator disajikan pada Gambar 1. 


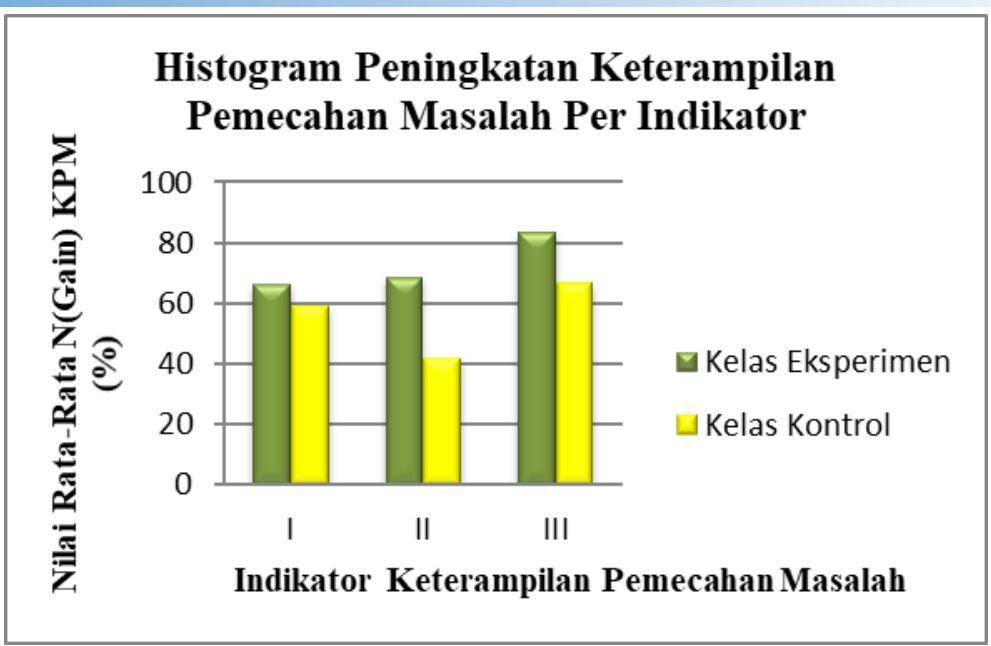

Fig. 1. Histogram Peningkatan Keterampilan Pemecahan Masalah Per Indikator Keterampilan Pemecahan Masalah

Keterangan:

I. Menganalisis permasalahan

II. Mengumpulkan data/informasi

III. Mengusulkan solusi pemecahan masalah

Keterampilan pemecahan masalah merupakan suatu bentuk keterampilan yang diperlukan untuk memecahkan permasalahan dalam membangun konsep pengetahuan. Implementasi model pembelajaran Project Based Learning (PjBL) pada pembelajaran IPA terpadu tipe connected diharapkan dapat meningkatkan keterampilan pemecahan masalah siswa seiring dengan latihan pemecahan masalah yang dilakukan melalui proses penyelidikan. Peningkatan keterampilan pemecahan masalah siswa pada kelas eksperimen dan kelas kontrol dianalisis berdasarkan nilai $\mathrm{N}$ gain yang diperoleh dari hasil pretest dan postest.

\subsubsection{Uji Statistik Keterampilan Pemecahan Masalah}

Sebelum dilakukan uji hipotesis, dilakukan uji normalitas untuk nilai pretest, dan N-gain dengan menggunakan uji Shapiro-Wilk menggunakan program aplikasi IBM SPSS Statistics 22. Rekapitulasi uji statistik nilai pretest keterampilan pemecahan masalah disajikan pada Tabel 6.

Tabel 6. Rekapitulasi Uji Statistik Nilai Pretest Keterampilan Pemecahan Masalah

\begin{tabular}{cccccccc}
\hline \multirow{2}{*}{ Pretest } & $\mathbf{N}$ & \multicolumn{2}{c}{ Uji Normalitas } & Uji Homogenitas & Uji t \\
\cline { 2 - 6 } Eksperimen & 21 & Sig. & Interpretasi & Sig. & Interpretasi & Sig. & Interpretasi \\
\hline Kontrol & 21 & 0,481 & $\begin{array}{c}\text { Distribusi } \\
\text { Data Normal } \\
\text { Distribusi } \\
\text { Data Normal }\end{array}$ & 0,110 & $\begin{array}{c}\text { Varians Data } \\
\text { Homogen }\end{array}$ & 0,077 & $\begin{array}{c}\text { Tidak terdapat } \\
\text { perbedaan } \\
\text { signifikan }\end{array}$ \\
\hline
\end{tabular}

Sebagai rumusan hipotesis untuk uji statistik nilai pretes keterampilan pemecahan masalah adalah sebagai berikut:

$\mathrm{H}_{0} \quad \mu_{1}=\mu_{2}$

Tidak terdapat perbedaan keterampilan pemecahan masalah secara signifikan antara siswa kelas eksperimen dan kelas kontrol

$\mathrm{H}_{1} \quad \mu_{1} \neq \mu_{2}$

Terdapat perbedaan keterampilan pemecahan masalah secara signifikan antara siswa kelas eksperimen dan kelas kontrol

Tabel 6 mengindikasikan bahwa data pretest kelas eksperimen dan kelas kontrol terdistribusi normal. Uji selanjutnya yang dilakukan adalah uji parametrik $t$-test. Berdasarkan hasil uji $t$ terhadap nilai pretest keterampilan pemecahan masalah diperoleh signifikansi Asymp. Sig. (2-tailed) adalah 
0,077> 0,05 berarti $\mathrm{H}_{0}$ diterima dan $\mathrm{H}_{1}$ ditolak. Jadi dapat disimpulkan bahwa tidak terdapat perbedaan kemampuan awal keterampilan pemecahan masalah antara siswa kelas eksperimen dan kontrol.

Peningkatan pencapaian keterampilan pemecahan masalah dianalisis berdasarkan nilai $\mathrm{N}$-gain. Untuk mengetahui signifikansi peningkatan keterampilan pemecahan masalah pada kelas eksperimen dan kelas kontrol, maka dilakukan pengujian terhadap nilai N-gain. Rekapitulasi uji statistik nilai N-gain pada kelas eksperimen dan kontrol disajikan pada Tabel 7.

Tabel 7. Rekapitulasi Uji Statistik Nilai N-Gain Keterampilan Pemecahan Masalah

\begin{tabular}{|c|c|c|c|c|c|c|c|}
\hline \multirow{2}{*}{ Pretest } & \multirow{2}{*}{$\begin{array}{c}N \\
\text { (Jumlah) }\end{array}$} & \multicolumn{2}{|c|}{ Uji Normalitas } & \multicolumn{2}{|c|}{ Uji Homogenitas } & \multicolumn{2}{|r|}{ Uji t } \\
\hline & & Sig. & Interpretasi & Sig. & Interpretasi & Sig. & Interpretasi \\
\hline Eksperimen & 21 & 0,184 & $\begin{array}{c}\text { Distribusi } \\
\text { Data Normal }\end{array}$ & & Varians Data & & Terdapat \\
\hline Kontrol & 21 & 0,371 & $\begin{array}{c}\text { Distribusi } \\
\text { Data Normal }\end{array}$ & 0,125 & Homogen & 0,000 & $\begin{array}{c}\text { perbedaan } \\
\text { signifikan }\end{array}$ \\
\hline
\end{tabular}

Berdasarkan Tabel 7 diperoleh data dari uji normalitas nilai N-gain kelas eksperimen dan kontrol terdistribusi dengan normal. Uji statistik selanjutnya yang dilakukan adalah uji parametrik t-test menggunakan program IBM SPSS Statistics 22. Sebagai rumusan hipotesis untuk peningkatan keterampilan pemecahan masalah siswa adalah sebagai berikut:

$\mathrm{H}_{0} \quad \mu_{1} \leq \mu_{2}$

Model PjBL tidak lebih baik dalam meningkatkan keterampilan pemecahan masalah secara signifikan dibandingkan dengan pembelajaran yang tidak menggunakan model PjBL

$\mathrm{H}_{1} \quad \mu_{1}>\mu_{2}$

Model PjBL tidak lebih baik dalam meningkatkan keterampilan pemecahan masalah secara signifikan dibandingkan dengan pembelajaran yang tidak menggunakan model PjBL

Berdasarkan hasil uji t pada data nilai $\mathrm{N}$-gain keterampilan pemecahan masalah, diperoleh nilai signifikansi Sig. (1-tailed) 0.000. Nilai 0,000 itu menunjukkan hasil yang lebih kecil dari 0,050 yang berarti $\mathrm{H}_{0}$ ditolak dan $\mathrm{H}_{1}$ diterima. Oleh karena itu, pada taraf kepercayaan 95\% $(\alpha=5 \%)$ diperoleh kesimpulan bahwa model pembelajaran PjBL lebih baik dalam meningkatkan keterampilan pemecahan masalah siswa dibandingkan dengan pembelajaran yang tidak menggunakan model PjBL.

\subsubsection{Tanggapan Siswa terhadap Model Pembelajaran Project Based Learning}

Data tanggapan siswa terhadap penerapan model pembelajaran latihan inkuiri dibagi atas 8 indikator. Data hasil tanggapan siswa pada Tabel 8.

Tabel 8. Hasil Perhitungan Angket Tanggapan Siswa terhadap Model Pembelajaran Project Based Learning

\begin{tabular}{|c|c|c|c|c|}
\hline No. & Pernyataan & $\begin{array}{c}\text { Skor } \\
\text { Rata-rata }\end{array}$ & $\begin{array}{l}\text { Persentase Capaian } \\
\text { Skor terhadap Skor } \\
\text { Maksimal (\%) }\end{array}$ & Kategori \\
\hline 1. & $\begin{array}{l}\text { Model pembelajaran PjBL merupakan } \\
\text { kegiatan pembelajaran yang baru bagi siswa }\end{array}$ & 3,76 & 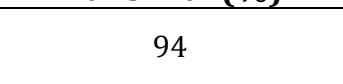 & $\begin{array}{l}\text { Sangat } \\
\text { Setuju }\end{array}$ \\
\hline 2. & $\begin{array}{l}\text { Model pembelajaran PjBL merupakan } \\
\text { pembelajaran yang menarik dan memotivasi } \\
\text { siswa }\end{array}$ & 3,28 & 82 & $\begin{array}{l}\text { Sangat } \\
\text { Setuju }\end{array}$ \\
\hline 3. & $\begin{array}{l}\text { Model pembelajaran PjBL dapat mengatasi } \\
\text { kesulitan siswa dalam memahami konsep } \\
\text { IPA }\end{array}$ & 3,09 & 77 & $\begin{array}{l}\text { Sangat } \\
\text { Setuju }\end{array}$ \\
\hline 4. & $\begin{array}{l}\text { Senang tidaknya siswa belajar kelompok } \\
\text { menggunakan model pembelajaran PjBL }\end{array}$ & 3,11 & 78 & $\begin{array}{l}\text { Sangat } \\
\text { Setuju }\end{array}$ \\
\hline 5. & $\begin{array}{l}\text { Model pembelajaran PjBL dapat mengatasi } \\
\text { kesulitan siswa dalam menyelesaikan tugas- } \\
\text { tugas yang diberikan oleh guru }\end{array}$ & 3,31 & 83 & $\begin{array}{l}\text { Sangat } \\
\text { Setuju }\end{array}$ \\
\hline 6. & $\begin{array}{l}\text { Model pembelajaran PjBL dapat } \\
\text { meningkatkan keterampilan siswa dalam }\end{array}$ & 2,90 & 73 & Setuju \\
\hline
\end{tabular}




\begin{tabular}{|c|c|c|c|c|}
\hline No. & Pernyataan & $\begin{array}{c}\text { Skor } \\
\text { Rata-rata }\end{array}$ & $\begin{array}{l}\text { Persentase Capaian } \\
\text { Skor terhadap Skor } \\
\text { Maksimal (\%) }\end{array}$ & Kategori \\
\hline 7. & $\begin{array}{c}\text { merancang percobaan } \\
\text { Model pembelajaran latihan inkuiri dapat } \\
\text { menumbuhkan keterampilan pemecahan } \\
\text { masalah }\end{array}$ & 3,57 & 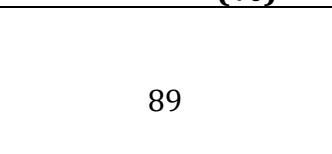 & $\begin{array}{l}\text { Sangat } \\
\text { Setuju }\end{array}$ \\
\hline
\end{tabular}

Berdasarkan hasil analisis angket, tanggapan siswa terhadap model pembelajaran PjBL secara garis besar siswa memberikan tanggapan sangat setuju bahwa model pembelajaran ini dapat memberikan beberapa perubahan siswa dalam belajar dimana siswa menyatakan bahwa model pembelajaran ini dapat memotivasi siswa untuk belajar, dapat membantu siswa dalam mengatasi kesulitan siswa dalam memahami konsep IPA, dapat mengatasi kesulitan siswa dalam menyelesaikan tugas-tugas yang diberikan oleh guru, serta dapat menumbuhkan keterampilan pemecahan masalah bagi siswa.

\subsection{Pembahasan}

Keterampilan pemecahan masalah merupakan suatu keterampilan berpikir yang diawali dengan permasalahan yang menuntut siswa untuk menyelesaikannya (Tawil \& Liliasari, 2013, p.90). Keterampilan ini sebagai salah satu keterampilan berpikir yang bisa dikembangkan melalui penerapan model pembelajaran PjBL. Keterampilan ini diukur menggunakan soal essay di mana masing-masing soal memuat tiga indikator keterampilan masalah yang disesuaikan dengan model PjBL. Pada awalnya tingkat kemampuan keterampilan pemecahan masalah siswa pada kelas eksperimen dan kontrol adalah sama. Secara statistik juga diperoleh Asymp. Sig. (2-tailed) adalah $0,077>0,05$ berarti dapat ditarik kesimpulan bahwa tidak terdapat perbedaan yang signifikan kemampuan awal keterampilan pemecahan masalah siswa kelas eksperimen dan kelas kontrol, sehingga peningkatan keterampilan pemecahan masalah layak diukur pada kelas eksperimen dan kelas kontrol ini.

Postest dilaksanakan pada kedua kelas sampel penelitian untuk melihat peningkatan keterampilan pemecahan masalah setelah perlakuan berupa implementasi model PjBL pada pembelajaran terpadu tipe connected dilaksanakan pada kelas eksperimen. Hasil rata-rata nilai postest menunjukkan adanya peningkatan kemampuan keterampilan pemecahan masalah yang dicapai oleh siswa pada kelas eksperimen maupun siswa pada kelas kontrol. Rata-rata postest keterampilan pemecahan masalah yang diperoleh oleh siswa kelas eksperimen adalah 79,97 sedangkan rata-rata yang diperoleh oleh siswa kelas kontrol adalah 74,71 yang menunjukkan perbedaan pencapaian nilai akhir dari kedua kelas sampel. Rata-rata nilai postest pada kelas eksperimen dan kontrol yang lebih tinggi dibandingkan dengan nilai pretest menunjukkan bahwa terjadi peningkatan keterampilan pemecahan masalah setelah diberi perlakuan melalui penerapan model pembelajaran PjBL dengan pembelajaran terpadu tipe connected pada kelas eksperimen.

Siswa kelas eksperimen dan kelas kontrol sama-sama mengalami peningkatan pencapaian keterampilan pemecahan masalah. Besar perbedaan pencapaian peningkatan keterampilan pemecahan masalah dapat dianalisis berdasarkan perolehan $\mathrm{N}$-gain kelas eksperimen dan kontrol. Berdasarkan perolehan nilai rata-rata $\mathrm{N}$-gain dari keterampilan pemecahan masalah dapat dilihat bahwa besar peningkatan ketercapaian keterampilan pemecahan masalah kelas eksperimen adalah 0,73 dengan kategori peningkatan tinggi sedangkan besar peningkatan ketercapaian keterampilan pemecahan masalah kelas kontrol adalah 0,63 dengan kategori peningkatan sedang. Berdasarkan hasil analisis uji statistika pada rata-rata nilai $\mathrm{N}$-gain diperoleh Sig. (1-tailed) $0.000<0,05$ berarti $\mathrm{H}_{0}$ ditolak dan $\mathrm{H}_{1}$ diterima, maka diperoleh kesimpulan bahwa penerapan model $\mathrm{PjBL}$ dengan pembelajaran terpadu tipe connected dapat meningkatkan keterampilan pemecahan masalah siswa secara signifikan dibandingkan dengan siswa yang belajar melalui pembelajaran konvensional. Jadi, penerapan model $\mathrm{PjBL}$ pada pembelajaran IPA terpadu dapat meningkatkan keterampilan pemecahan masalah siswa SMP/MTs secara signifikan dibandingkan dengan pembelajaran yang tidak menggunakan model PjBL.

Grant (2002, p. 5) mendefinisikan PjBL atau pembelajaran berbasis proyek merupakan model pembelajaran yang berpusat pada peserta didik untuk melakukan suatu investigasi yang mendalam terhadap suatu topik. Peserta didik secara konstruktif melakukan pendalaman pembelajaran dengan pendekatan berbasis riset terhadap permasalahan dan pertanyaan yang berbobot, nyata, dan relevan. Pembelajaran ini dibangun diatas aktivitas dan tugas nyata yang memberikan tantangan bagi siswa 
terkait dengan kehidupan sehari-hari untuk dipecahkan secara berkelompok. PjBL menciptakan lingkungan belajar "konstruktivis" dimana peserta didik membangun pengetahuan mereka sendiri.

PjBL sebagai strategi untuk melahirkan siswa yang kreatif dalam memecahkan permasalahan yang nyata dalam kehidupan mereka dengan merancang, merencanakan, mengorganisir dan menerapkan proses pembelajaran. Kreativitas siswa menjadi titik sentral dalam pengembangan dan implementasi PjBL ini. Siswa akan membuat hubungan yang kuat antarkonsep ketika mempelajari fakta dan siswa dengan aktif bekerja melalui informasi yang diperolehnya dalam proses pemecahan masalah. Jadi, dalam proses pembelajaran dengan model PBL telah melatih siswa untuk bisa mendayagunakan pengetahuan awalnya sebagai modal awal untuk memperoleh konsep pengetahuan baru melalui proses penyelidikan yang dilakukan.

\section{Simpulan}

Penerapan model pembelajaran Project Based Learning (PjBL) pada pembelajaran IPA terpadu tipe connected dapat meningkatkan keterampilan pemecahan masalah pada indikator menganalisis masalah, mengumpulkan data/informasi, dan mengusulkan solusi pemecahan masalah. Pada pembelajaran IPA terpadu, penerapan model pembelajaran $P j B L$ dapat lebih baik dalam meningkatkan keterampilan pemecahan masalah secara signifikan. Siswa memberikan tanggapan yang positif terhadap penerapan model $P j B L$ pada pembelajaran IPA terpadu tipe connected. Berdasarkan analisis terhadap angket tanggapan siswa terhadap penerapan model PjBL, diperoleh interpretasi bahwa siswa sangat setuju terhadap implementasi model PjBL dalam pembelajaran IPA terpadu.

\section{Daftar Pustaka}

Baran, M. \& Maskan, A. (2010). The Effect of Project-based Learning on Pre-service Physics Teachers. Cypriot Journal of Educational Sciences Electrostatic Achievements. 5. 243-257.

Fogarty, R. 1991a. How to Integrate The Curricula. Illionis: IRI/Skylight Publishing, Inc.

Fraenkel, J. R. \&Wallen, N. E. (2007). How to Design and Evaluate Research in Education. New York: McGraw-Hill.

Grant, M. M. (2002). Getting A Grip of Project Based Learning: Theory, Cases and Recomandation. North Carolina. Meredian: A Middle School Computer Technologies Journal. Vol. 5, 1-17.

Hake, R. (1999). Analyzing Change/ Gain Score. Indiana: Indiana University.

Ismuwardani, dkk. (2019). Implementation of Project Based Learning Model to Increased Creativity and Self-Reliance of Students on Poetry Writing Skills. Journal of Primary Education, 8(1), 51-58.

Jamaludin, D.N. (2013). Pengaruh Project Based Learning terhadap Berpikir Kritis, Berpikir Kreatif, dan Sikap Ilmiah pada Materi Tumbuhan Biji. Tesis, tidak diterbitkan. Universitas Pendidikan Indonesia.

Kaya, D., Izgiol, D. \& Kesan, C. (2014). The Investigation of Elementary Mathematics Teacher Candidates; Problem Solving Skills According to Various Variables. International Electronic Journal of Elementary Education, 6(2), 295-314.

Nofrianita, (2015). Penerapan Project based Learning dan Problem based Learning dalam Pembelajaran IPA Terpadu tipe Connected untuk Meningkatkan Penguasaan Konsep dan Keterampilan Berpikir Siswa. Tesis, tidak diterbitkan. Universitas Pendidikan Indonesia.

Peraturan Menteri Pendidikan dan Kebudayaan Republik Indonesia Nomor 85 Tahun 2013. (2013). Kurikulum 2013 Sekolah Menengah Pertama/Madrasah Tsanawiyah. Jakarta: Kemendikbud.

Rezeki, dkk. (2015). Penerapan Metode Pembelajaran Project Based Learning (PjBL) Disertai dengan Peta Konsep untuk Meningkatkan Prestasi dan Aktivitas Belajar Siswa pada Materi Redoks Kelas X-3 SMA Negeri Kebakkramat Tahun Pelajaran 2013 / 2014. Jurnal Pendidikan Kimia, 4(1), 74-81. 
Tawil, M. \& Liliasari. (2013). Berpikir Kompleks dan Implementasinya dalam Pembelajaran IPA. Makassar: Badan Penerbit UNM.

The George Locas Educational. (2005). Project Based Learning. Retrieved from http://www.edutopia.org.

Toharudin, U., Hendrawati, S. \& Rustaman, A., (2011). Membangun Literasi Sains Peserta Didik. Bandung: Humaniora.

Trianto, (2014). Model Pembelajaran Terpadu Cetakan Keenam. Jakarta: Bumi Aksara. 